\title{
Lessons from tissue-specific KO of CNP/GC-B system - everlasting challenge to clinical application
}

Kazuwa Nakao*, Koitiro Kuwahara, Hiroaki Yasoda, Goro Katuura, Kazuhiro Nakao, Kazumasa Nakao, Yui Yamasita

From 6th International Conference on cGMP: Generators, Effectors and Therapeutic Implications

Erfurt, Germany. 28-30 June 2013

Since the identification of the first natriuretic peptide, ANP, from the atrium of the heart, thirty years have passed and clinical applications have been achieved in ANP.BNP/GC-A system. In contrast with the distribution of the ANP-BNP/GC-A system as the endocrine system, the CNP/GC-B system is distributed as the paracrine/ autocrine system.

In order to assess physiological rolls of the CNP/GC-B system, we have developed tissue -specific knockout mice using the Cre-Lox-P system. Here, we present results of both CNP knockout mice and GC-B knockout mice in the brain, bone and cardiovascular system and discuss the possible physiological and pathophysiological implications of the CNP/GC-B system.

Published: 29 August 2013

doi:10.1186/2050-6511-14-S1-O4

Cite this article as: Nakao et al:: Lessons from tissue-specific KO of CNP/ GC-B system - everlasting challenge to clinical application. BMC

Pharmacology and Toxicology 2013 14(Suppl 1):04.
* Correspondence: nakao@kuhp.kyoto-u.ac.jp

Medical Innovation Center and Dept. of Med. and Clin. Sci., Kyoto Univ. Graduate School of Med., Kyoto, Japan
Submit your next manuscript to BioMed Central and take full advantage of:

- Convenient online submission

- Thorough peer review

- No space constraints or color figure charges

- Immediate publication on acceptance

- Inclusion in PubMed, CAS, Scopus and Google Scholar

- Research which is freely available for redistribution 